\title{
ANALISIS FAKTOR - FAKTOR YANG MEMPENGARUHI KEPUTUSAN BERKUNJUNG KE HOTEL DI KOTA JEMBER PADA SAAT PANDEMI COVID-19
}

\author{
Hadi Jatmiko, Syah Riza Octavy Sandy ${ }^{2}$ \\ Program Perhotelan, Fakultas Ilmu Sosial dan Ilmu Politik \\ Universitas Muhammadiyah Jember, Indonesia \\ Email : hadijatmiko@unmuhjember.ac.id
}

\begin{abstract}
Abstrak
Penelitian ini akan membahas anlisis tentang Analisis Faktor - Faktor Yang Mempengaruhi Keputusan Berkunjung ke Hotel di Kota Jember Pada Saat Pandemi Covid-19. Sehingga melalui penelitian ini dapat memberikan sumbangan pemikiran kepada pelaku usaha jasa perhotelan mengambil kebijakan untuk meningkatkan tingkat kunjungan tamu dalam situasi pendemi Covid-19 saat ini. Penelitian ini bertujuan Untuk (1) menganalisis faktor - faktor yang mempengaruhi keputusan berkunjung ke hotel di kota Jember pada saat pandemi Covid-19, (2) menganalisis faktor dominant yang mempengaruhi keputusan berkunjung ke hotel di Kota Jember pada saat pandemi Covid-19. Populasi dari penelitian ini adalah tamu yang memutuskan berkunjung di hotel dengan proposional Random Sampling sejumlah 100 responden, wawancara terstruktur dengan asosiasi pengelola hotel. Hasil penelitian menunjukan bahwa (1) Secara simultan: Faktor protokol kesehatan, kemampuan staf, aksesibilitas, dan fasilitas kamar terbukti berpengaruh secara bersama-sama terhadap Keputusan Berkunjung Tamu Pada saat Pandemi Covid19 di kota Jember, (2). Kemampuan staf berpengaruh dominan terhadap Keputusan Berkunjung Tamu Pada saat Pandemi Covid19 di kota Jember. Hal ini menunjukkan bahwa staff hotel harus memahami pelayanan pada saat pandemi covid-19 terutama tentang protokol kesehatan.
\end{abstract}

Kata Kunci : Keputusan Berkunjung, Hotel, Pandemi Covid-19

\begin{abstract}
This study will discuss an analysis of the analysis of factors affecting the decision to visit hotels in Jember City during the Covid-19 pandemic. So that through this research it can contribute ideas to hotel service business actors in making policies to increase the level of guest visits in the current Covid-19 pandemic situation. This study aims to (1) analyze the factors that influence guests 'decisions to stay at hotels during the Covid-19 pandemic, (2) analyze the dominant factors that influence guests' decisions to stay at hotels during the Covid-19 pandemic. The population of this study were guests who decided to visit the hotel with proportional random sampling of 100 respondents, structured interviews with hotel management associations. The results showed that (1) Simultaneously: Health protocol factors, staff capability, accessibility, and room facilities were proven to influence jointly on guest visiting decisions during the Covid19 pandemic in Jember, (2) Staff ability has a dominant influence on Guest Visit Decisions during the Covid19 Pandemic in the city of Jember. This shows that hotel staff must understand services during the Covid-19 pandemic, especially regarding health protocols.
\end{abstract}

Keywords: Visiting Decisions, Hotels, Covid-19 Pandemic 


\section{INTRODUCTION}

Kenyamanan dan keamanan menjadi tuntutan utama bagi pengguna jasa perhotelan pada saat pandemi Covid-19 ini. Hal ini menuntut setiap pengelola di industri perhotelan ini selalu meningkatkan kualitas pelayanannya untuk menajdi pilihan pertama bagi pengunjung sebagai pengguna jasa.

Bisnis hotel saat pandemi seperti ini cenderung menurun, hal ini sangat bergantung pada kepercayaan dan rasa aman kepada pengunjung serta pelayanan yang sudah umum diberikan karyawan kepada pengunjung.

Kabupaten Jember sebagai salah satu kota yang terdampak Covid 19 per September mencatatkan 784 kasus positif dan meninggal sebanyak 53 orang (Data Pemprov Jatim). Kondisi ini membuat bisnis perhotelan merasakan imbas penurunan kunjungan ke hotel di Kota Jember.

Pasca penerapan kenormalan baru oleh pemerintah, sejak 1 Juli 2020 lalu pengelola Hotel di Kota Jember telah membuka kembali hotel. Untuk menarik pengunjung, pengelola hotel membuat promosi salah satunya dengan penurunan tarif sewa kamar. Selain itu, pihak hotel juga perlu menampilkan langkah pencegahan yang dilakukan melalui website atau media sosial. Tujuannya, pengunjung akan lebih yakin ketika hendak memilih tempat penginapan saat pandemi virus belum usai..

Muttaqin dan Dhewi ( 2015) memaparkan dalam hasil penelitiannya bahwa (1) fasilitas berpengaruh terhadap keputusan menginap pengguna jasa Hotel Pelangi Dua Malang, (2) lokasi berpengaruh terhadap keputusan menginap pengguna jasa Hotel Pelangi Dua Malang. Penelitian ini dilakukan sebelum adanya pandemi covid-19.

Perilaku pengunjung untuk menginap pada saat pandemi menjadi kunci bagi pengelola hotel untuk meningkatkan tingkat kunjungannya. Tingkat kunjungan tamu hotel di Jember yang rata - rata menurun saat pandemi Covid-19 dikarenakan salah satunya oleh perilaku pengunjung yang masih ragu untuk menginap di hotel.

\section{METODOLOGI}

Variabel dari penelitian ini adalah:

Variabel X : Faktor - faktor pengaruh keputusan berkunjung ke hotel pada saat Pandemi Covid-19

Varibel Y : Keputusan berkunjung ke hotel pada saat Pandemi Covid-19

Sumber data :

1. Data primer adalah data utama yang diperoleh melalui kuisioner dari responden, atau juga data hasil wawancara peneliti dengan nara sumber langsung dari lokasi penelitian, seperti keadaan atau kondisi hotel di kota Jember. Jumlah sampelnya 100 responden pengunjung hotel.

2. Data sekunder adalah data pendukung dari penelitian yang dilakukan. Data ini diperoleh dari beberapa sumber yaitu studi-studi kepustakaan, serta data-data yang diperoleh dari pihak terkait dengan bisnis hotel di Kota Jember.

Adapun tahap analisis data penelitian ini adalah sebagai berikut :

1. Regresi Linier Berganda

Tujuannya untuk mengetahui besarnya pengaruh Protokol Kesehatan, kemampuan staff, fasilitas kamar, aksesibilitas (variabel bebas). Keputusan Berkunjung Tamu ke Hotel (variabel terikat) yang formulasinya sebagai berikut (Supranto, 2001:236)

$\mathrm{Y}=\mathrm{a}+\mathrm{b}_{1} \mathrm{X}_{1}+\mathrm{b}_{2} \mathrm{X}_{2}+\mathrm{b}_{3} \mathrm{X}_{3}+\mathrm{b}_{4} \mathrm{X}_{4}+\mathrm{e}$

Keterangan:

$\mathrm{Y}=$ Keputusan Berkunjung Tamu ke Hotel Pada saat Pandemi Covid-19

a $\quad=$ Konstanta

$\mathrm{b}_{1 \ldots} \mathrm{b}_{4}=$ Koefisien regresi

$\mathrm{X}_{1} \quad=$ Protokol Kesehatan

$\mathrm{X}_{2} \quad=$ Kemampuan staff

$\mathrm{X}_{3} \quad=$ Aksesbilitas 
$\mathrm{X}_{4} \quad=$ Fasilitas kamar

e =variabel gangguan

Analisis regresi dilakukan sebagai uji statistik dalam rangka mengetahui faktorfaktor yang mempengaruhi keputusan berkunjung tamu hotel di kota Jember pada saat Pandemi Covid-19.

2. Pengujian Terhadap Hipotesis Penelitian.

Uji signifikansi komponen Protokol Kesehatan, kemampuan staff,bfasilitas kamar, aksesibilitas (variabel bebas) terhadap keputusan berkunjung tamu ke hotel di Kota Jember (variabel terikat) secara simultan akan diuji dengan uji F (Ftest), sedangkan untuk yang serentak akan diuji dengan uji statistik $\mathrm{t}$ (t-test).

\section{RESULT AND DISCUSSION}

\section{a. Analisis Deskriptif Variabel Penelitian}

Deskripsi variabel penelitian berguna untuk mendukung hasil analisis data. Hasil analisis statistik deskriptif dapat disarikan dalam tabel berikut :

Tabel 1. Analisis Deskriptif Skor Jawaban

Responden

\begin{tabular}{|c|c|c|c|c|}
\hline Variabel & Indikator & Mean & Modus & Kategori Variabel \\
\hline \multirow{7}{*}{$\begin{array}{l}\text { Faktor } \\
\text { Protokol } \\
\text { Kesehatan } \\
\text { (X1) }\end{array}$} & $\mathrm{X} 1.1$ & 4,14 & 4 & \multirow{7}{*}{ Baik } \\
\hline & $\mathrm{X} 1.2$ & 4,04 & 4 & \\
\hline & $\mathrm{X} 1.3$ & 4,06 & 4 & \\
\hline & $\mathrm{X} 1.4$ & 4,07 & 4 & \\
\hline & $\mathrm{X} 1.5$ & 4,00 & 4 & \\
\hline & $\mathrm{X} 1.6$ & 4,06 & 4 & \\
\hline & $\mathrm{X} 1$ & 4,06 & 4 & \\
\hline \multirow{6}{*}{$\begin{array}{c}\text { Kemampuan } \\
\text { Staf (X2) }\end{array}$} & $\mathrm{X} 2.1$ & 3,97 & 4 & \multirow{6}{*}{ Baik } \\
\hline & $\mathrm{X} 2.2$ & 4,01 & 4 & \\
\hline & $\mathrm{X} 2.3$ & 3,89 & 4 & \\
\hline & $\mathrm{X} 2.4$ & 3,77 & 4 & \\
\hline & $\mathrm{X} 2.5$ & 3,80 & 4 & \\
\hline & $\mathrm{X} 2$ & 3,89 & 4 & \\
\hline \multirow{4}{*}{$\begin{array}{c}\text { Aksesibilitas } \\
\text { (X3) }\end{array}$} & $\mathrm{X} 3.1$ & 4,07 & 4 & \multirow{4}{*}{ Baik } \\
\hline & $\mathrm{X} 3.2$ & 4,21 & 4 & \\
\hline & $\mathrm{X} 3.3$ & 4,18 & 4 & \\
\hline & $\mathrm{x} 3$ & 4,15 & 4 & \\
\hline \multirow{5}{*}{$\begin{array}{c}\text { Fasilitas } \\
\text { Kamar (X4) }\end{array}$} & $\mathrm{X} 4.1$ & 3,96 & 4 & \multirow{5}{*}{ Baik } \\
\hline & $\mathrm{X} 4.2$ & 3,85 & 4 & \\
\hline & $\mathrm{X} 4.3$ & 3,93 & 4 & \\
\hline & $\mathrm{X} 4.4$ & 3,76 & 3 & \\
\hline & $\mathrm{X} 4$ & 3,87 & 4 & \\
\hline \multirow{5}{*}{$\begin{array}{l}\text { Keputusan } \\
\text { Berkunjung } \\
\text { (Y) }\end{array}$} & Y1 & 4,25 & 4 & \multirow{5}{*}{ Baik } \\
\hline & Y2 & 3,96 & 4 & \\
\hline & Y3 & 3,94 & 4 & \\
\hline & Y4 & 3,93 & 4 & \\
\hline & $\mathrm{Y}$ & 4,02 & 4 & \\
\hline
\end{tabular}

Berdasarkan Tabel 1. diatas dapat dinyatakan berkaitan dengan variabel faktor protokol kesehatan (X1) menghasilkan persepsi "baik" dari sebagian besar responden dengan bukti bahwa nilai mean secara keseluruhan 4,06 dan modus sebesar 4. Baiknya persepsi terhadap variabel faktor protokol kesehatan dapat dilihat melalui pemasangan media informasi oleh manajemen hotel di lokasi strategis terkait ketentuan protokol kesehatan; managemen hotel mewajibkan pemeriksaan suhu tubuh setiap tamu yang mau masuk hotel; manajemen hotel menerapkan jaga jarak (social distancing), hotel menyediakan handsanitizer di area yang tamu sering berada; manajemen hotel mengoptimalkan sirkulasi udara dan sinar matahari sehingga kualitas udara tetap terjaga ; Manajemen hotel rutin melakukan pembersihan filter AC, serta manajemen hotel melakukan disinfektan pada area yang sering digunakan tamu seperti lift, toilet, dan fasilitas umum lainnya.

Berkaitan dengan variabel kemampuan staf (X2) menghasilkan persepsi "baik" dari sebagian besar responden dengan bukti bahwa nilai mean secara keseluruhan 3,89 dan modus sebesar 4. Baiknya persepsi terhadap variabel kemampuan staf dapat dilihat melalui staf hotel mampu bekerja sesuai dengan keahlian sesuai bidangnya, staf hotel mampu menguasai teknis yang ada di hotel terutama pada saat pandemi covid-19, staf hotel senantiasa meningkatkan layanan hotel pada saat pandemi covid-19, staf hotel mempunyai kemampuan dalam mengelola informasi tentang keamanan dan kenyamanan pengunjung pada saat pandemi covid-19, dan staf hotel selalu menjunjung tinggi standar pelayanan.

Berkaitan dengan variabel aksesibilitas (X3) menghasilkan persepsi "baik" dari sebagian besar responden dengan bukti bahwa nilai mean secara keseluruhan 4,15 dan modus sebesar 4. Baiknya persepsi terhadap variabel aksesibilitas dapat dilihat melalui tersedia jalan yang baik untuk mengunjungi Hotel di Jember, tersedia transportasi yang memadai untuk mengunjungi Hotel di Jember, dan 
tersedia fasilitas umum dan pendukung untuk mengunjungi Hotel di Jember.

Berkaitan dengan variabel fasilitas kamar (X4) menghasilkan persepsi "baik" dari sebagian besar responden dengan bukti bahwa nilai mean secara keseluruhan 3,87 dan modus sebesar 4. Baiknya persepsi terhadap variabel fasilitas kamar dapat dilihat melalui tersedia fasilitas kamar yang layak, tersedia fasilitas akses internet yang memadai, perlengkapan dan peralatan di kamar berkualitas, serta pelayanan kamar dinilai memenuhi standar.

Berkaitan dengan variabel keputusan berkunjung (Y) menghasilkan persepsi "baik" dari sebagian besar responden dengan bukti bahwa nilai mean secara keseluruhan 4,02 dan modus sebesar 4. Baiknya persepsi terhadap variabel keputusan berkunjung dapat dilihat melalui keputusan menginap di hotel sesuai dengan kebutuhan, konsumen mencari informasi dari berbagai sumber sebelum memutuskan untuk menginap di hotel, konsumen melakukan perbandingan dan menyeleksi berbagai hotel sebelum memutuskan untuk menginap di hotel, dan setelah konsumen mengunjungi hotel di Jember, konsumen akan tetap memilih dan selalu menginap di hotel tersebut.

\section{b. Analisis Regresi Linier Berganda}

Pengujian pada analisis regresi linear berganda bertujuan mengetahui tingkat pengaruh variabel independen (faktor protokol kesehatan, kemampuan staf, aksesibilitas, dan fasilitas kamar) terhadap variabel dependen (keputusan berkunjung). Berdasarkan pengujian diperoleh hasil yang dapat disajikan dalam tabel berikut :

Tabel 2. Hasil Perhitungan Regresi Linear Berganda

\begin{tabular}{|l|c|c|c|c|}
\hline \multicolumn{1}{|c|}{ Variabel } & Koef. Regresi & $\mathbf{t}_{\text {hitung }}$ & Sig. & Keterangan \\
\hline Konstanta & 2,797 & 2,248 & 0,028 & - \\
\hline $\mathrm{X} 1$ & 0,104 & 2,159 & 0,035 & Signifikan \\
\hline $\mathrm{X} 2$ & 0,249 & 4,049 & 0,000 & Signifikan \\
\hline $\mathrm{X} 3$ & 0,196 & 2,293 & 0,025 & Signifikan \\
\hline $\mathrm{X} 4$ & 0,224 & 3,408 & 0,001 & Signifikan \\
\hline & & $\mathrm{R}$ & 0,805 \\
& & $\mathrm{R}^{2}$ & 0,648 \\
& & $\mathrm{~F}_{\text {hitung }}$ & 30,396 \\
& & F Sig. & 0,000 \\
& & $\mathrm{n}$ & 71 \\
\hline
\end{tabular}

Berdasarkan tabel diatas, maka persamaan regresi linier berganda yang diperoleh adalah :

$\mathrm{Y}=2,797+0,104 \mathrm{X}_{1}+0,249 \mathrm{X}_{2}+0,196 \mathrm{X}_{3}+$ $0,224 \mathrm{X}_{4}$

Hasil perhitungan diatas menjelaskan bahwa :

1. Konstanta sebesar 2,797, menunjukkan besarnya keputusan berkunjung pada saat variabel faktor protokol kesehatan, kemampuan staf, aksesibilitas, dan fasilitas kamar sama dengan nol. Dalam hal ini keputusan berkunjung masih tercapai meskipun tanpa kelima variabel tersebut yang disebabkan oleh faktor lain.

2. $\mathrm{b}_{1}=0,104$, artinya apabila variabel kemampuan staf, aksesibilitas, dan fasilitas kamar sama dengan nol, maka peningkatan variabel faktor protokol kesehatan sebesar satu satuan akan meningkatkan keputusan berkunjung sebesar 0,104 satuan.

3. $b_{2}=0,249$ artinya apabila variabel faktor protokol kesehatan, aksesibilitas, dan fasilitas kamar sama dengan nol, maka peningkatan variabel kemampuan staf sebesar satu satuan akan meningkatkan keputusan berkunjung sebesar 0,249 satuan.

4. $b_{3}=0,196$ artinya apabila variabel faktor protokol kesehatan, kemampuan staf, dan fasilitas kamar sama dengan nol, maka peningkatan variabel aksesibilitas sebesar satu satuan akan meningkatkan keputusan berkunjung sebesar 0,196 satuan.

5. $\mathrm{b}_{4}=0,224$ artinya apabila variabel faktor protokol kesehatan, kemampuan staf, dan aksesibilitas sama dengan nol, maka peningkatan variabel fasilitas kamar sebesar 
satu satuan akan meningkatkan keputusan berkunjung sebesar 0,224 satuan

\section{c. Analisis Koefisien Determinasi Berganda}

$\left(\mathbf{R}^{2}\right)$.

Berdasarkan pada Tabel 2 terkait dengan hasil analisisnya, maka 1 koefisien determinasi berganda $\left(\mathrm{R}^{2}\right)$ yang diperoleh sebesar 0,648, hal ini berarti $64,8 \%$ perubahan keputusan berkunjung dipengaruhi oleh variabel faktor protokol kesehatan, kemampuan staf, aksesibilitas, dan fasilitas kamar sedangkan sisanya sebesar 35,2\% disebabkan oleh faktor lain seperti kualitas layanan, harga, citra, dan lainnya yang tidak termasuk dalam persamaan regresi yang dibuat.

\section{d. Pengujian Hipotesis}

1. Hasil Uji F

Uji $F$ ini bertujuan untuk mengetahui pengaruh variabel faktor protokol kesehatan, kemampuan staf, aksesibilitas, dan fasilitas kamar terhadap keputusan berkunjung secara bersama-sama. Berdasarkan Tabel 2 dapat dilihat bahwa nilai $\mathrm{F}$ hitung sebesar 30,396 lebih besar daripada $F$ tabel $(2,50)$ dan nilai probabilitas $(\mathrm{P}$ value $)<0,05$ atau $(0,000<$ $0,05)$ maka dinyatakan faktor protokol kesehatan, kemampuan staf, aksesibilitas, dan fasilitas kamar terbukti berpengaruh secara bersama-sama terhadap Keputusan Berkunjung Tamu Pada saat Pandemi Covid19 di kota Jember.

2. Hasil Uji t

a) Pengaruh variabel faktor protokol kesehatan $\left(\mathrm{X}_{1}\right)$ terhadap keputusan berkunjung $(\mathrm{Y})$

Variabel faktor protokol kesehatan $\left(\mathrm{X}_{1}\right)$ memiliki $t_{\text {hitung }}>\mathrm{t}_{\text {tabel }}$ yaitu 2,159 $>1,994$ serta signifikansi $<\alpha$ yaitu $0,035<0,05$. Karena $t_{\text {hitung }}>t_{\text {tabel }}$ dan tingkat probabilitasnya lebih kecil dari 5\%, maka secara parsial variabel faktor protokol kesehatan berpengaruh signifikan terhadap keputusan berkunjung Tamu Pada saat Pandemi Covid19 di kota Jember.

b) Pengaruh variabel kemampuan staf $\left(\mathrm{X}_{2}\right)$ terhadap keputusan berkunjung $(\mathrm{Y})$

Variabel kemampuan staf $\left(\mathrm{X}_{2}\right)$ memiliki $t_{\text {hitung }}>t_{\text {tabel }}$ yaitu 4,049>1,994 serta signifikansi $<\alpha$ yaitu $0,000<0,05$. Karena $t_{\text {hitung }}>t_{\text {tabel }}$ dan tingkat probabilitasnya lebih kecil dari 5\%, maka secara parsial variabel kemampuan staf berpengaruh signifikan terhadap keputusan berkunjung Tamu Pada saat Pandemi Covid19 di kota Jember.

c) Pengaruh variabel aksesibilitas $\left(\mathrm{X}_{3}\right)$ terhadap keputusan berkunjung (Y)

Variabel aksesibilitas $\left(\mathrm{X}_{3}\right)$ memiliki $\mathrm{t}_{\text {hitung }}>\mathrm{t}_{\text {tabel }}$ yaitu $2,293>1,994$ serta signifikansi $<\alpha$ yaitu $0,025<0,05$. Karena $t_{\text {hitung }}>t_{\text {tabel }}$ dan tingkat probabilitasnya lebih kecil dari 5\%, maka secara parsial variabel aksesibilitas berpengaruh signifikan terhadap keputusan berkunjung Tamu Pada saat Pandemi Covid19 di kota Jember.

d) Pengaruh variabel fasilitas kamar $\left(\mathrm{X}_{4}\right)$ terhadap keputusan berkunjung $(\mathrm{Y})$

Variabel fasilitas kamar $\left(\mathrm{X}_{4}\right)$ memiliki $t_{\text {hitung }}>t_{\text {tabel }}$ yaitu $3,408>1,994$ serta signifikansi $<\alpha$ yaitu $0,001<0,05$. Karena $t_{\text {hitung }}>t_{\text {tabel }}$ dan tingkat probabilitasnya lebih kecil dari 5\%, maka secara parsial variabel fasilitas kamar berpengaruh signifikan terhadap keputusan berkunjung Tamu Pada saat Pandemi Covid19 di kota Jember.

3. Hasil Analisis Koefisien Korelasi Parsial ( $\left.r_{\text {partial }}\right)$

Analisis koefisien korelasi parsial digunakan untuk mengetahui variabel bebas mana yang dominan terhadap variabel terikat yaitu dengan melihat variabel yang memiliki nilai $t_{\text {hitung }}$ tertinggi serta nilai signifikansi (sig.) terkecil. Berdasarkan hasil tersebut, dapat disimpulkan bahwa 
dari kelima variabel (faktor protokol kesehatan, kemampuan staf, aksesibilitas, dan fasilitas kamar) yang memiliki pengaruh dominan terhadap keputusan berkunjung Tamu Pada saat Pandemi Covid19 di kota Jember adalah variabel kemampuan staf $\left(\mathrm{X}_{2}\right)$.

4. Hasil analisis regresi dari pengujian statistik dengan Uji $\mathrm{F}$ dan $\mathrm{t}$ adalah :

Uji regresi mennghasilkan bahwa variabel faktor protokol kesehatan, kemampuan staf, aksesibilitas, dan fasilitas kamar terbukti berpengaruh secara bersamasama terhadap Keputusan Berkunjung Tamu Pada saat Pandemi Covid19 di kota Jember. Hal ini memberikan gambaran bahwa konsumen atau tamu yang akan berkunjung ke hotel mempertimbangkan faktor protokol kesehatan, kemampuan staf, aksesibilitas, dan fasilitas kamar sebagai aspek penting dalam memutuskan untuk mengunjungi hotel khususnya saat Pandemi Covid19 di kota Jember. variabel faktor protokol kesehatan berpengaruh positif dan signifikan terhadap keputusan berkunjung. Pengujian secara statistik ini membuktikan bahwa semakin baiknya persepsi atas variabel faktor protokol kesehatan yang meliputi media informasi, pemeriksaan suhu, social distancing, hand sanitizer, kualitas udara, dan pembersihan serta disinfeksi maka akan menyebabkan Keputusan Berkunjung Tamu Pada saat Pandemi Covid19 di kota Jember meningkat.

Uji regresi mennghasilkan bahwa variabel kemampuan staf berpengaruh positif dan signifikan terhadap keputusan berkunjung. Pengujian secara statistik ini membuktikan bahwa semakin baiknya persepsi atas variabel kemampuan staf dapat dilihat melalui staf hotel mampu bekerja sesuai dengan keahlian sesuai bidangnya, staf hotel mampu menguasai teknis yang ada di hotel terutama pada saat pandemi covid-19, staf hotel senantiasa meningkatkan layanan hotel pada saat pandemi covid-19, staf hotel mempunyai kemampuan dalam mengelola informasi tentang keamanan dan kenyamanan pengunjung pada saat pandemi covid-19, dan staf hotel selalu menjunjung tinggi standar pelayanan, maka akan menyebabkan Keputusan Berkunjung Tamu Pada saat Pandemi Covid19 di kota Jember meningkat meningkat.

Uji regresi mennghasilkan bahwa variabel aksesibilitas berpengaruh positif dan signifikan terhadap keputusan berkunjung. Pengujian secara statistik ini membuktikan bahwa semakin baiknya persepsi atas variabel aksesibilitas meliputi tersedia jalan yang baik untuk mengunjungi Hotel di Jember, tersedia transportasi yang memadai untuk mengunjungi Hotel di Jember, dan tersedia fasilitas umum dan pendukung untuk mengunjungi Hotel di Jember maka akan menyebabkan Keputusan Berkunjung Tamu Pada saat Pandemi Covid19 di kota Jember meningkat meningkat.

Uji regresi mennghasilkan bahwa variabel fasilitas kamar berpengaruh positif dan signifikan terhadap keputusan berkunjung. Pengujian secara statistik ini membuktikan bahwa semakin baiknya persepsi atas variabel fasilitas kamar meliputi tersedia fasilitas kamar yang layak, tersedia fasilitas akses internet yang memadai, perlengkapan dan peralatan di kamar berkualitas, serta pelayanan kamar dinilai memenuhi standar maka akan menyebabkan Keputusan Berkunjung Tamu Pada saat Pandemi Covid19 di kota Jember meningkat meningkat.

Uji regresi mennghasilkan bahwa dari kelima variabel (faktor protokol kesehatan, kemampuan staf, aksesibilitas, dan fasilitas kamar) yang memiliki pengaruh dominan terhadap keputusan berkunjung Tamu Pada saat Pandemi Covid19 di kota Jember adalah variabel kemampuan staf $\left(\mathrm{X}_{2}\right)$. Mengacu pada hasil tersebut dapat dinilai bahwa kemampuan staf merupakan ujung tombak dalam 
pemberian pelayanan yang baik kepada tamu hotel. Pihak hotel senantiasa dituntut untuk mampu meningkatkan kemampuan staf hotel dan aspek ini akan menjadi penentu bagi tamu dalam memutuskan untuk mengunjungi dan menggunakan jasa hotel.

\section{KESIMPULAN}

Hasil pembahasan diatas dapat disimpulkan menjadi beberapa hal yaitu:

1. Hasil identifikasi faktor-faktor yang mempengaruhi Keputusan Berkunjung Tamu Pada saat Pandemi Covid-19 di kota Jember:

a. Secara simultan: Faktor protokol kesehatan, kemampuan staf, aksesibilitas, dan fasilitas kamar terbukti berpengaruh secara bersama-sama terhadap Keputusan Berkunjung Tamu Pada saat Pandemi Covid19 di kota Jember;

b. Secara parsial:

1) Faktor protokol kesehatan berpengaruh terhadap Keputusan Berkunjung Tamu Pada saat Pandemi Covid19 di kota Jember.

2) Kemampuan staf berpengaruh terhadap Keputusan Berkunjung Tamu Pada saat Pandemi Covid19 di kota Jember.

3) Aksesibilitas berpengaruh terhadap Keputusan Berkunjung Tamu Pada saat Pandemi Covid19 di kota Jember.

4) Fasilitas kamar berpengaruh terhadap Keputusan Berkunjung Tamu Pada saat Pandemi Covid19 di kota Jember.

2. Kemampuan staf berpengaruh dominan terhadap Keputusan Berkunjung Tamu Pada saat Pandemi Covid19 di kota Jember. Hal ini menunjukkan bahwa staff hotel harus memahami pelayanan pada saat pandemi covid-19 terutama tentang protokol kesehatan.

\section{DAFTAR PUSTAKA}

Annishia, Prastiyo. 2019. Pengaruh Harga Dan Fasilitas Terhadap Keputusan Menginap Tamu Di Hotel Best Western Premier The Hive Jakarta, Jurnal Hospitality dan Pariwisata Vol.4 (No. 1): 1 - 85. Th. 2019.

Riski. 2015. Keputusan Konsumen Dalam Memilih Hotel Pangeran Pekanbaru Riau. JOM FISIP Vol 2 No. 2 Oktober 2015

Darsono Agustinus. 2001. Kantor Depan Hotel. PT.Gramedia Widiasarana Indonesia: Jakarta

https://id.wikipedia.org/wiki/Pandemi_COVID $\underline{-19}$, ( akses agustus 2020)

https://tirto.id/apakah-yang-dimaksudprotokol-kesehatan-covid-19-f3W3, (akses Nopember 2020)

Kotler, Philip.. 2008.Manajemen Pemasaran Jilid I (Edisi ke-13). Erlangga, Jakarta Mustika Zed, Metode Penelitian Kepustakaan, Jakarta: Yayasan Obor Nasional, 2004

Muttaqin, Dhewi. (2015). Pengaruh Fasilitas dan Lokasi Terhadap Keputusan Menginap : Jurnal Ekonomi Bisnis Tahun 20, Nomor 2, Juli 2015, hlm 53-138

, Ir, MM. 1997. Operasional Kantor Depan. PT. Gramedia Pustaka Utama: Jakarta.

Singarimbun Masri dkk, 1989, Metode Penelitian Survey. Gramedia Jakarta

Sugiarto Endar, Ir, MM. 1996. Pengantar Akomodasi Dan Restoran. PT. Gramedia Pustaka Utama: Jakarta

Sugiyono. (2014). Metode Penelitian Pendidikan Pendekatan Kuantitatif, Kualitatif Dan R\&D. Bandung: Alfabeta

Swastha, Basu dan Irawan. 1997. Manajemen Pemasaran Modern. Edisi kelima, Yogyakarta : Liberty. 
Tjiptono, Fandi. 2001. "Strategi Pemasaran". Edisi kedua, Yogyakarta : Andi

Wahab, Salah. 1997. Pemasaran Pariwisata. Jakarta : PT. Pradya Paramitha. 